Sergii I. Azarov ${ }^{1}$, D. S. (Engineering), Senior Research Associate

ORCID ID 0000-0002-9951-8867e-mail: azarov@kinr.kiev.ua

Oleksii S. Zadunaj ${ }^{2}$, PhD (Engineering), Head of the center

ORCID ID 0000-0001-8589-1604 e-mail:a.zadunaj@gmail.com

${ }^{1}$ Institute for Nuclear Research of NASU, Kyiv, Ukraine

${ }^{2}$ State Research Institute of Special Communications and Information Protection, Kyiv, Ukraine

\title{
ASSESSMENT OF STABILITY OF ECOSYSTEMS
}

Summary. The transformation of ecosystem behavior with the change of unstable equilibrium persistent imbalances in the light of nonlinear dynamics. The task of ensuring the sustainability of ecosystems inseparable from the search admissible class of perturbations that it can withstand and not lose with the stability of their condition or movement. Focusing the analysis on the nature of the perturbations corresponds to the classical theory approach, because the essence of the stability concept is in calculation of numerical values of the perturbations for the given deviation estimates rather than in nature of the change of the perturbed movement versus undisturbed.

The paper proposes expansion of methodological means of investigation and stability sustaining of the ecosystems through involvement of traditional system approaches. The analysis of ecosystem diversity, accompanied by justification of ordering options that allows us to formulate the principle of sufficiency in ecosystems, enter the parameters of heterogeneity and irregularity of states to classify these ecosystems.

Keywords: stability of ecosystems; ecosystem; equilibrium; external influences; ecological reserve; perturbation; trajectory

\section{С.I. Азаров ${ }^{1}$, О.С. Задунай ${ }^{2}$}

${ }^{1}$ Інститут ядерних досліджень НАН України, м. Київ, Україна

${ }^{2}$ Державний науково-дослідний інститут спеціального зв'язку та захисту інформації, м. Київ, Україна

\section{АНАЛІЗ СТІЙКОСТІ ЕКОСИСТЕМ}

Анотація. Трансформація поведінки екосистем зі зміною нестійкої рівноваги стійким дисбалансом розглядається під кутом зору нелінійної динаміки. Завдання забезпечення стійкості екосистем невід'ємне від пошуку класу допустимих збурень, які вона може витримати і не втратити при иьому стійкості свого стану або руху. Фокусування аналізу на характері збурень відповідає і духу класичного вчення, оскільки сутність поняття стійкості не стільки в характері зміни величин відхилень збуреного руху від незбуреного, а скільки в оцінках численних величин збурень при заданих оцінках ијих відхилень. В статті обтрунтовується розширення методологічного апарату дослідження та підтримки стійкості екосистем, завдяки залученню традииійних системних підходів. Проводиться аналіз різноманітності станів екосистеми, який супроводжується обтрунтуванням параметрів їх

(C) S.I. Azarov, O.S. Zadunaj, 2019

ISSN: 2411-4049. Екологічна безпека та природокористування, № 3 (31), 2019 
впорядкованості, що дозволяе сформулювати принцип достатності в екосистемах, ввести параметри неоднорідності і нерегулярності ї̈ станів для класифікації ицих екосистем.

Ключові слова: стійкість екосистем; екосистема; стан рівноваги; зовнішні впливи; екологічний резерв; збурення; траєкторія

\section{Вступ}

В аспекті забезпечення переходу суспільства на засади сталого розвитку важливого значення набуває оцінка ризиків втрати, знищення екосистем, що тісно пов'язано з їхньою стійкістю. Стійкість екосистем розглядається як здатність зберігати свою структуру і характер функціонування в просторі та часі під впливом змін умов зовнішнього середовища [1].

Стійкість $є$ фундаментальною властивістю природних екосистем. Стійкість екосистеми - один 3 найбільш значущих показників стану навколишнього середовища. Вона являє собою здатність екосистеми в цілому та іï складових частин успішно протистояти негативним зовнішнім чинникам, зберігаючи при цьому не тільки свою структуру, але й свої функції [2]. Її можна розглядати як незмінність певного стану екосистеми, так і як здатність переходу до будь-яких інших станів у даний час (статична стійкість) i неперервність розвитку екосистеми (динамічна стійкість). Поняття стійкості тісно пов'язане із здатністю екосистеми повертатися в стан рівноваги після припинення зовнішніх впливів, які вивели ії зі стану рівноваги, а також з поняттям стабільності.

Стійкість не завжди означає здатність підтримки екосистемою рівноважного стану, хоча спочатку явище стійкості трактували саме так. Загальновідомо [3], що для біологічних систем характерне явище гомеостазу і їхня стійкість полягає в підтримці певних параметрів стану в межах деякого постійного рівня. Принциповим у переході від розгляду технічної системи до розгляду екосистеми $є$ те, що в останньої відхилення реальних траєкторій розвитку від траєкторії мети відбуваються випадково і отримати точну інформацію про ці відхилення неможливо. I якщо про стійкість технічної системи можна стверджувати однозначно, аналізуючи диференціальні рівняння, що характеризують поведінку системи, то скласти диференціальні рівняння функціонування екосистеми здебільшого неможливо. Тому висновки про стійкість або нестійкість екосистеми можна робити тільки 3 певною імовірністю. Найбільш стійкими є великі екосистеми, і найстабільніша 3 них біосфера, а найбільш нестійкі - молоді екосистеми. Це пояснюється тим, що у великих екосистемах створюється саморегулюючий гомеостаз за рахунок взаємодії кругообігу речовин і потоків енергії. Природа наслідує принцип «змінюватись, щоб зберігатись», і в процесі еволюції матерії виникли різні механізми стійкості. Залежно від механізмів розвитку і типу втрати стійкості екосистеми можна виділити декілька типів криз [4]:

a) критична ситуація;

b) власна криза;

c) катастрофа.

Перші характеризуються механізмами адаптивного розвитку екосистеми, другі - м'якою втратою стійкості екосистеми, треті - жорсткою втратою стійкості. Стійкість екосистеми до негативних зовнішніх чинників визначається iii здатністю протистояти цьому впливу та зберігати нормальне функціонування 
(здатність до відновлення після припинення негативного впливу та повернення зі зміненого стану до нормального режиму функціонування). Для оцінки стійкості екосистем щодо природних криз та антропогенних порушень доцільно застосувати поняття про екологічний резерв екосистеми. Екологічний резерв екосистеми - це різниця між гранично допустимим відхиленням та фактичним станом екосистеми. Вона вказує на розміри тієї буферної зони, в межах якої можливі зміни, що не руйнують екосистему. На жаль, методів оцінки екологічного резерву екосистем різного типу поки що немає. У багатьох випадках екологічний резерв екосистем оцінюється інтуїтивно, «на око». Тому наукові розробки в цьому напрямку є дуже актуальними.

\section{Зміст і корінні риси атрибута стійкості екосистем}

Дослідження стійкості динамічних екосистем має багату історію, але до сих пір в цьому пізнавальному процесі не вирішені теоретико-методологічні та інструментальні проблеми, в подоланні яких беруть діяльну участь фізики, математики, кібернетики, біологи, екологи та їх колеги з інших галузей науки.

У природі ми зустрічаємо більше нелінійних процесів в будь-якій динамічній екосистемі, ніж лінійних в чистому вигляді.

Позначимо незбурений стан в екосистемах $\mathrm{z}(\mathrm{t})$, а збурення - $\mathrm{x}(\mathrm{t})$. Тоді незбурений стан $\mathrm{z}(\mathrm{t})$ будемо називати стійким, якщо для будь-якого $\varepsilon>0$ можна вказати [5]:

$$
\delta\left(E, t_{0}\right)>0
$$

таке, що з нерівності

$$
\left|\mathrm{x}\left(\mathrm{t}_{0}\right)-\mathrm{z}\left(\mathrm{t}_{0}\right)\right|<\Delta\left(\varepsilon, \mathrm{t}_{0}\right)
$$

випливає нерівність

$$
|x(t)-z(t)|<E
$$

при $\mathrm{t} \geq 0$.

Для ілюстрації стійкого стану екосистеми на рис. 1 зображена трубка траєкторій в околиці незбуреного стану $z(\mathrm{t})$, а також область початкових умов 3 радіусом $\delta$.

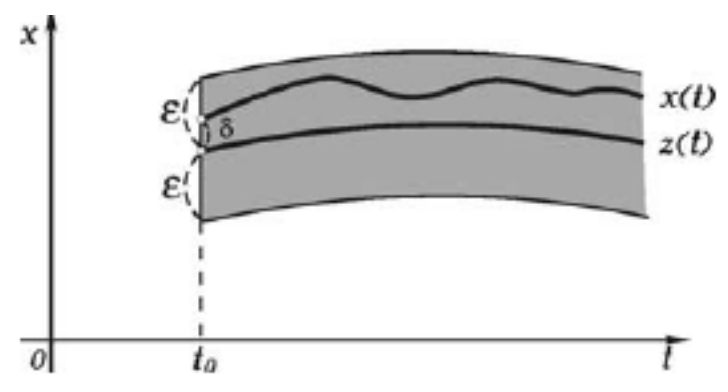

Рис. 1 - Стійкість екосистеми, яка змінюється в часі (величина z (t)) 
Стійкість екосистеми означає, що якою би вузькою не була трубка уздовж траєкторії незбуреного стану екосистеми, збурення іiі стану, що почалося в $\delta$-околиці, яка дорівнює або менша $\varepsilon$-околиці заданої початкової точки, буде залишатися в зазначеній $\varepsilon$-трубці. Підкреслимо, що визначення стійкості екосистеми має на увазі виконання двох видів обмежень: з одного боку, обмежується сукупність початкових збурень, а 3 іншого боку, обмежується реакція на них - зміна стану в екосистемі. У всіх випадках, коли ці обмеження дотримуються, кажуть, що збурені стани екосистеми сходяться до незбурених.

Збурений стан екосистеми може сходитися до незбурених в звичайному сенсі з виконанням двох згаданих обмежень, а може протікати в «посиленому» режимі - асимптотично, коли збурений стан екосистеми не тільки обмежений областю допустимих відхилень, але різниця між збуреним і незбуреним іiі станом стає все менше і менше і на межі зменшується до нуля. У другому випадку має місце асимптотична стійкість незбуреного стану екосистеми. Інакше кажучи, екосистема, яка володіє властивістю асимптотичної стійкості, після дії збурень відновлює свій процес в тому вигляді, яким він був би за відсутності цих збурень. Наочними прикладами асимптотичної стійкості траєкторії, яка не тільки залишається в як завгодно малій трубці уздовж незбуреної траєкторії, але і прагне з плином часу до незбуреного стану, можуть служити ілюстрації на рис. 2 i 3.

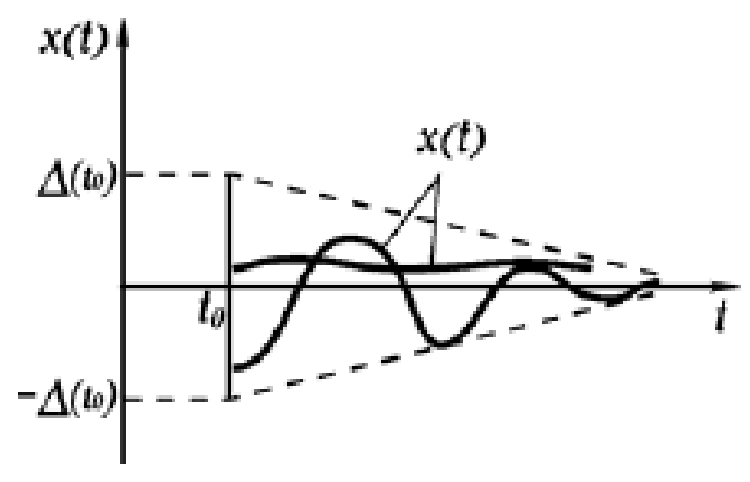

Рис. 2 - Асимптотична стійкість екосистеми для нульового рішення

На першому з них обмежена інтервалом $\pm \Delta\left(\mathrm{t}_{0}\right)$ хвилеподібна траєкторія випрямляється і врешті-решт зливається з незбуреним (нульовим) рішенням $x(\mathrm{t})$ (рис. 2), а на другому траєкторія $x(\mathrm{t})$ спрямована до початку координат i 3 кожним витком наближається до нього (рис. 3). Таким чином, порівнюючи стійкість і асимптотичну стійкість, правомірно зробити висновок, що забезпечення асимптотичної стійкості екосистеми є більш жорстким, оскільки додатково вводиться вимога повернення до незбуреного стану екосистеми. 


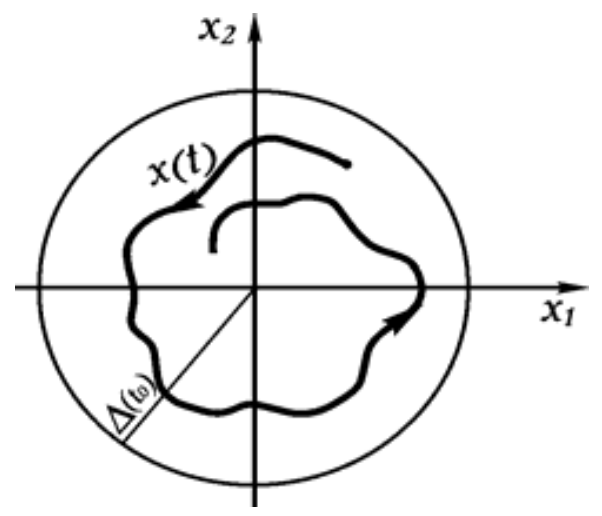

Рис. 3 - Фазовий портрет асимптотично стійкої траєкторії екосистеми

Для констатації нестійкості незбуреного стану екосистеми достатньо мати хоча б одну траєкторію, яка навіть при малих збуреннях виходить за межі області допустимих відхилень $\varepsilon$-околиці (рис. 4).

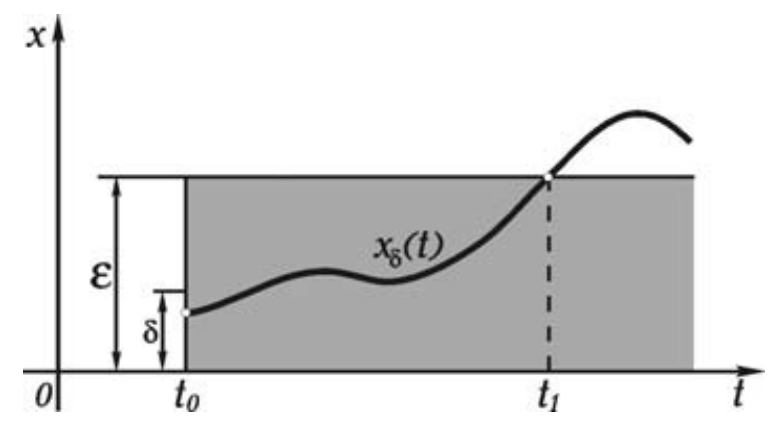

Рис. 4 - Нестійкість змінюється в часі (величини $\left.x_{\delta}(\mathrm{t})\right)$

На рис. 4 видно, що в момент часу $\mathrm{t}_{1}$ траєкторія $\mathrm{x}_{\delta}(\mathrm{t})$ перетинає $\varepsilon$-трубку $\mathrm{i}$ «вистрибує» 3 неї, що вказує на нестійкість незбуреного стану екосистеми. У цьому тлумаченні стійкого стану екосистеми важливо підкреслити залежність $\delta$-околиці від величини $\varepsilon$-трубки: адже $\delta$ вибирається, виходячи 3 наперед заданої області $\varepsilon$-трубки, внаслідок чого для кожної $\varepsilon$-трубки існує своя $\delta$-околиця. Але аж ніяк не для кожної величини $\delta$ можна знайти таку $\varepsilon$-околицю, яка обмежить траєкторію стану екосистеми $3 \delta$-околиці.

Звернемо увагу і на ту обставину, що не всякий стан екосистеми може бути стійким. Відносно одних станів можна стверджувати про їх стійкість, тоді як відносно інших - ні. Тому слід спеціально обумовлювати, які траєкторії і змінні екосистеми аналізуються на стійкість. Доведено, що в однієї і тієї ж екосистеми одні стани можуть бути стійкими, а інші - нестійкими. I навіть один і той же стан екосистеми може бути стійким щодо однієї змінної і нестійким відносно іншої. Серед розділів загальної теорії управління самою розвиненою $\epsilon$ теорія автоматичного управління, для якої вирішення питання про стійкість екосистеми є першим основним завданням. В зв'язку 3 цим видається обгрунтованим звернення до проблематики стійкості екосистеми 3 позицій методології та інструментарію цієї теорії. В іiі рамках вивчення стійкості передбачає оперування величиною похибки, в даному випадку - 
розбіжності між незбуреним і збуреним станом екосистеми. При дослідженні iii залежності від часу насамперед постає запитання про те, яка динамічна картина перехідного процесу, зокрема тривалість періоду переходу екосистеми в кінцевий стан після впливу збурень. Справа в тому, що через запізнювання і інерційність процесів, що протікають в екосистемах, вона реагує на дії не відразу, і тому подібний перехід відбувається не миттєво, а протягом деякого часу. Сутність стійкості змінюється в залежності від того, чи є досліджувана екосистема лінійною або нелінійною. Стійкість лінійної екосистеми має на увазі ії повернення після дії зовнішніх збурень в початковий стан. У нелінійній екосистемі протікають більш складні процеси, і для іiі стійкості вважають за можливе, щоб траєкторія стану екосистеми 3 припиненням впливу зовнішніх збурень залишалася в заданій області. Тому коливальний рух в лінійній екосистемі $\epsilon$ ознакою піi нестійкості, тоді як в нелінійній екосистемі, навпаки, може бути цілком «правильним» і свідчити про їі стійкість.

Відносно до коливального руху в лінійній екосистемі стійкість - це атрибут поведінки екосистеми на нескінченному проміжку часу, що виражає властивість даної екосистеми:

- несуттєво відхилятися від деякого руху при малих збуреннях початкового положення екосистеми, причому доля відхилення рівномірна;

- несуттєво відхилятися від деякого стійкого стану при малих збуреннях як початкового положення екосистеми, так і самого закону зміни (стійкість при постійно діючих збуреннях).

Іноді малі збурення початкового положення підкоряються деякій додатковій умові (умовна стійкість), або доля збурення і відхилення вимірюється лише за деякими параметром (стійкість за частиною змінних). Нижче наведений приклад витіюватої траєкторії, стійкої лише за змінною $x$, яка обмежена допустимим інтервалом $\pm \varepsilon$ (рис. 5);

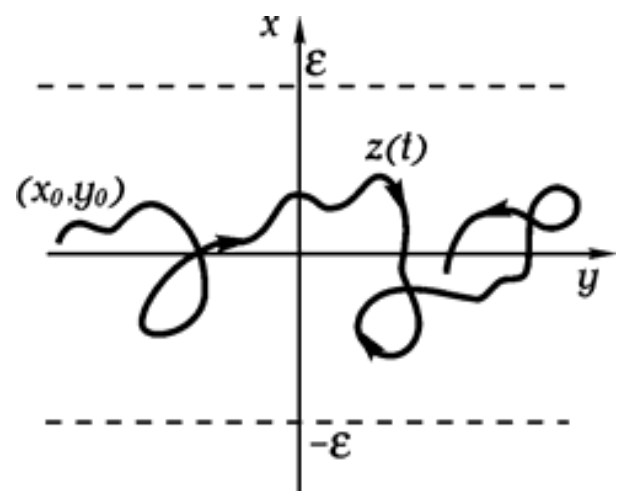

Рис. 5 - Траєкторія, яка стійка за змінною $x$

- зберігати деякі властивості (мовою математики «риси фазового портрета») при малих збуреннях;

- залишатися в обмеженій області фазового простору, тобто в просторі значень змінних екосистеми;

- врешті-решт повертатися як завгодно близько до свого початкового стану. 
Кожен 3 цих атрибутів відповідає конкретному типу досліджуваної екосистеми і характеру завдання, яке може бути поставлене в тій або іншій формі.

Крім станів абсолютної стійкості або нестійкості, можуть мати місце і стани умовної і відносної стійкості, при яких відновлення рівноваги залежить від початкового зсуву екосистеми. Тому не можна не враховувати і збурення, внаслідок дії яких екосистема відхиляється від початкового стану.

Але якщо не можуть бути допустимими будь-які збурення, а лише ті з них, які задовольняють запропонованим вимогам, то незбурений рух стійкий лише для збурень, підпорядкованих певним умовам. Щоб надати математичний сенс цьому висновку, будемо вважати, що збурений рух називається стійким по відношенню до величин $y_{\mathrm{k}}$, якщо при будь-якому заданому позитивному числі $\varepsilon$, яким би малим воно не було, знайдеться інше позитивне число $\eta(\varepsilon)$, таке, що для всіх збурень $y_{k 0}$ задовольняє умовам:

$$
\left|y_{k 0}\right| \leq \eta(\varepsilon)(k=1, \ldots, n)
$$

збурений рух буде задовольняти нерівності:

$$
\left|y_{k}(\mathrm{t})\right|<\varepsilon(k=1, \ldots, n) .
$$

при будь-якому $\mathrm{t}>0$.

Зазначені умови набувають вирішального значення для теорії стійкості, i це зрозуміло. Адже при одних збуреннях стійкість руху системи може бути збережена, тоді як інші збурення можуть перевести екосистему в нестійкий стан. У підсумку можна констатувати, що завдання забезпечення стійкості екосистем невід'ємне від пошуку класу допустимих збурень, які вона може витримати i не втратити при цьому стійкості свого стану або руху. Фокусування аналізу на характері збурень відповідає i духу класичного вчення, оскільки сутність поняття стійкості не стільки в характері зміни величин відхилень збуреного руху від незбуреного, а скільки в оцінках численних величин збурень при заданих оцінках цих відхилень. Тим самим ми отримали розвиток уявлення про стійкість не тільки для малих збурень, а й для випадку, коли область збурень велика або навіть не обмежена. Уточнимо, що областю допустимих збурень даної області $\mathrm{G}$ називається така область Е, для якої виконується властивість: всі траєкторії, що виходять 3 іiі точок, не виходять за межі області G. Слід, однак, мати на увазі: із завданням області початкових умов для стану рівноваги часто не потрібно, щоб екосистема, яка змінюється, 3 плином часу поверталася знову до свого попереднього стану («покинутої» точки рівноваги). Для стійкості досить лише того, щоб екосистема залишалася в області допустимих відхилень. Справа в тому, що в екосистемах діють регулярні і нерегулярні сили, які вторгаються в поведінку екосистеми поблизу стану рівноваги. Вплив регулярних сил проявляється в «тяжінні» екосистеми до рівноваги або віддаленні від неї. Але і 3 наближенням екосистеми до рівноважного стану воно не може бути досягнуто в точності через дії нерегулярних сил флуктуаційного характеру, що змушують екосистему здійснювати малі рухи поблизу стану рівноваги. У тому випадку, з визнанням важливості вирішення завдання про величину області початкових умов (відхилень), доречно торкнутися і питання про область допустимих 
відхилень і пов'язаної з цим збіжності до незбуреного руху екосистеми. Адже якщо область початкових умов буде дуже малою, то система може залишатися в рамках заданої області допустимих відхилень. В іншому випадку, коли область початкових умов виходить за деякі межі, обмеженої області допустимих відхилень може і не бути. При цьому, якщо має місце збіжність до незбуреного руху, то вона може протікати асимптотично.

У тому випадку, якщо стійкість руху дотримується для досить малих початкових відхилень, кажуть про стійкість, локальну стійкість або стійкість «в малому». До речі, слід звернути увагу на те, що стійкість в малому зовсім не означає, що відхилення обов'язково повинні бути малими. В цьому випадку мають на увазі тільки те, що в околиці початку координат існує область тяжіння траєкторій в точці рівноваги, але ніяких вказівок на розміри цієї області немає, $\mathrm{i}$ тому стійкість екосистеми можна гарантувати лише в досить малій околиці початку координат. Слід зазначити, що властивість локальної стійкості екосистеми може ставитися і до траєкторій, якщо воно виконується тільки для тих з них, які проходять в достатній близькості від рівноважної траєкторії.

У розвиток концепції про стійкість «в малому» введемо поняття про стійкість «у великому». Воно містить в собі здатність підтримки стійкого руху і при порівняно великих початкових відхиленнях. Дослідження виявляють, що екосистема може бути стійкою «в малому», але нестійкою «у великому». Дійсно, при незначних відхиленнях від положення рівноваги вона може зберігати стійкість, наближаючись 3 плином часу до рівноважного стану, тоді як при великих відхиленнях від нього, навпаки, може віддалятися від стану рівноваги і втрачати стійкість. І якщо при яких завгодно збуреннях екосистема не демонструє стійкості руху, вона $є$ «нестійкою в великому». Тим часом не можна виключати і того, що екосистема збереже стійкий рух при будь-яких початкових відхиленнях, тобто область їі початкових умов не обмежена. Тоді $\epsilon$ підстави вважати таку екосистему не тільки стійкою «у великому», а й стійкою «в цілому». Область тяжіння в цьому випадку збігається 3 простором всіх станів екосистеми. Асимптотична збіжність обуреного руху екосистеми також розглядається крізь призму стійкості в малому, великому і цілому.

Тому, як і раніше, вид асимптотичної стійкості руху екосистеми залежить від величини відхилення іiі початкових умов. Зауважимо, що своєрідність додатків теорії стійкості до дослідження поведінки екосистем полягає в тому, що воно проводиться переважно в аспекті асимптотичної стійкості, за якої траєкторія руху екосистеми не тільки обмежена допуском, але і спрямовується до незбуреної траєкторії. Поширюючи погляди про стійкість «в малому» на асимптотичну стійкість, правомірно визначити: якщо при досить малих відхиленнях початкових умов траєкторія досліджуваної екосистеми $з$ часом зближується з незбуреною, то така траєкторія має властивість асимптотичної стійкості незбуреного руху або асимптотичної стійкості «в малому». Графічно така властивість руху екосистеми відображена на рис. 6.

На рис. 6 показано, що будь-яка траєкторія, яка в початковий момент часу мало відхиляється від незбуреної траєкторії $\mathrm{x}^{0}(\mathrm{t})$, тобто знаходиться в iํ околиці $\eta$, в подальшому зливається 3 цією незбуреною траєкторією. Продовжуючи аналогію зі стійкістю «у великому» (асимптотична стійкість «у великому» має місце в тому випадку, коли область відхилень початкових умов досить велика і кінцева), маємо асимптотичну стійкість «в цілому», коли ця область не обмежена. 


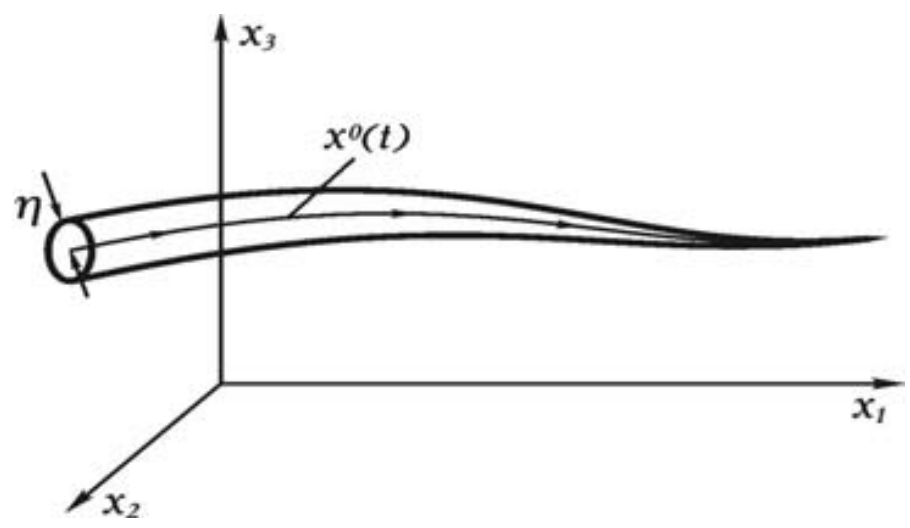

Рис. 6 - Ілюстрація асимптотичної стійкості незбуреного руху екосистеми

Точка рівноваги р називається локально стійкою, якщо для неї існує околиця, така, що для будь-якої іï точки $\mathrm{p}_{0}$ кожне рішення рівняння $\psi\left(\mathrm{t} ; \mathrm{p}_{0}\right)$ сходиться до точки рівноваги р, тобто

$$
\lim \psi\left(\mathrm{t} ; \mathrm{p}_{0}\right)=\mathrm{p}
$$

при $\mathrm{t} \rightarrow \infty$.

Якщо точка рівноваги р має властивість

$$
\lim \psi\left(\mathrm{T} ; \mathrm{p}_{0}\right)=\mathrm{p}
$$

при $\mathrm{T} \rightarrow \infty$ для всіх точок р 0 околиці $\mathrm{p}$ (або для кожного рішення рівняння $\left.\psi\left(\mathrm{T} ; \mathrm{p}_{0}\right)\right)$, вона називається глобально стійкою.

Останню також визначають тією властивістю, що область тяжіння екосистеми збігається з усім простором її станів; або ця властивість виконується для будь-якої траєкторії екосистеми (з тих, що розглядаються) і тому іноді називається глобальною стійкістю. Глобальну стійкість можна трактувати i 3 точки зору збурень, що зазнає екосистема. Оскільки викликані ними відхилення в цьому випадку нічим не лімітуються, то і самі збурення допускаються довільними. Важливо лише, щоб функції екосистеми задовольняли заданому класу функцій. Така стійкість екосистеми має місце за необмежених збурень і будь-якій нелінійній характеристиці регулюючого органу, визначеній лише $з$ точністю до приналежності до певного класу функцій.

Крім того, глобальну стійкість відносять до роду таких явищ, які незмінно ритмічно повторюються в природі, пов'язані 3 астрономічними закономірностями і тим самим дають привід для такого роду твердження.

Звернемо увагу на відносно стійкі явища, що існують лише в масштабі життя екосистеми. Тут відмітною ознакою абсолютної і відносної стійкості $€$ тривалість оцінюваної серії подій, що розвиваються.

Проблема дослідження стійкості руху екосистеми ускладнюється тим, що стосовно рівноваги можливий будь-який випадок: екосистема може не мати жодного стану рівноваги, володіти лише одним рівноважним станом або безліччю ї. Більш ніж один стан рівноваги характерний для нелінійних екосистем, яким властива непроста поведінка. У теорії автоматичного 
управління визнають, що в загальному випадку задача обчислення всіх рівноважних станів або перевірки існування хоча б одного такого нетривіальна i ii рішення не має загальних конструктивних прийомів. Якщо рівноважні стани екосистеми існують, то чисельні методи дозволяють 3 високою точністю виявити один або декілька подібних станів. Для цілей нашого дослідження будемо виходити 3 тлумачення поняття стійкості руху, яке склалося в природничих науках. Воно розкривається наступним чином: якщо підпорядковані накладеним умовам (варіаціям) збурення не викликають 3 часом позамежних відхилень значень спостережуваної функції, рух, що визначається нею, визнається стійким. Оскільки про стійкість можна судити за характером траєкторії руху екосистеми, то за формою поняття стійкості виражає таку властивість, що допустимі зміщення початкового положення траєкторії в подальшому залишають іï в заданих межах щодо незбуреного руху. Так, до категорії стійких (точніше, асимптотично стійких в цілому) будемо відносити зміну економічного показника, для якого доведено, що незалежно від його значення в початковий момент часу в будь-якому випадку воно асимптотично наближається до заданого значення показника.

Оскільки класичне визначення поняття стійкості інтерпретується по відношенню до рівноважного стану екосистеми та іiі дослідження має на увазі отримання однієї з двох відповідей (екосистема або стійка, або нестійка), обгрунтовуються поняття стійкості щодо поставленої мети і міра ступеня цієї стійкості. Завершуючи обговорення властивості стійкості екосистем, згадаємо і про те, що розробляється теорія збурень, яка займається методами наближеного рішення задач для «збурених» траєкторій, близьких до незбурених. Основний задум цієї теорії полягає в тому, що вибирається деяка ідеалізована екосистема, що має точний опис і містить один або кілька малих параметрів. При цьому 3 обнулінням таких параметрів одержувані рівняння дають можливість знайти точне рішення i дії аналітиків направляються на відшукання найкращого наближення до вирішення для збуреної траєкторії з тією або іншою точністю.

Ця обставина полегшує пошук рішення, але тільки на досить малих відрізках часу. Питання про те, якою мірою можна довіряти отриманим при цьому результатам на великі інтервали часу або нескінченність, поки ще вивчене недостатньо. Доведено і застосовуються на практиці критерії стійкості екосистем, які дозволяють визначити, чи зберігається властивість стійкості тих чи інших конкретних рішень або рухів екосистем. Зокрема, для лінійних стаціонарних екосистем $з$ постійними коефіцієнтами необхідною і достатньою умовою асимптотичної стійкості, з математичної точки зору, є негативність всіх речових (дійсних) коренів характеристичного рівняння. При цьому асимптотична стійкість такого рішення означає його асимптотичну стійкість в цілому (глобальну стійкість).

\section{Висновки}

3 аналізу наведених у даній роботі міркувань щодо стійкості екосистем можна зробити висновки, головні з яких такі.

1. Фундаментальне поняття стійкості рівноваги і руху екосистем має багатий зміст, різноманіття смислових відтінків і підходів до тлумачення, що надає iї дослідженню настільки ж «стійкий» інтерес і бажання знайти аналітичний інструмент для пізнання іiі властивостей. 
2. У природничо-науковій інтерпретації стійкість екосистеми являє собою відносну інваріантність іiі спостережуваних властивостей при дії допустимих збурень: здатність траєкторії руху залишатися в певних межах, незважаючи на втручання передбачених завданням збурень. При цьому в залежності від області початкових відхилень траєкторії розрізняють стійкість «в малому», «у великому» і «в цілому», а від характеру збіжності збуреного руху до незбурених - звичайну і асимптотичну стійкість.

\section{СПИСОК ЛІЕРАТУРИ}

1. Гродзинський М.Д. Стійкість геосистем до антропогенних навантажень / М.Д. Гродзинський. - К.: Лікей, 1995. 233 с.

2. Стійкість екосистем до радіаційних навантажень / I.В. Матвеєва, С.І. Азаров, Ю.О. Кутлахмедов, О.В. Харламова. - К.: НАУ, 2016. 396 с.

3. Азаров C.I. Аналіз характеристик існуючих екосистем / Азаров C.I., Сидоренко В.Л., Задунай О.С. // Науково-практичний журнал «Екологічні науки». 2017. - Вип. 3/4 (18-19/2017). - С. 77-85.

4. Азаров С.І. Визначення надійності екосистем до чинника антропогенного тиску / Азаров С.І., Сидоренко В.Л., Задунай О.С. // Збірник наукових праць «Екологічна безпека та природокористування». - 2017.- № 3-4 (24). - С. 50-57.

5. Азаров С.I. Моделювання стійкості екосистеми / Азаров С.I., Задунай О.С. // Науково-практичний журнал «Екологічні науки». - 2018. - №4 /2018 (23). - С. 5-9.

Стаття надійшла до редакиії 06.07.2019 і прийнята до друку після рецензування 30.07.2019

\section{REFERENCES (TRANSLATED AND TRANSLITERATED)}

1. Hrodzyns'kyy, M. D. (1995). Stiykist' heosystem do antropohennykh navantazhen'. Kyiv: Likey. (in Ukrainian).

2. Matveyeva, I. V., Azarov, S. I., Kutlakhmedov, Y. O., \& Kharlamova, O. V. (2016). Stiykist' ekosystem do radiatsiynykh navantazhen'. Kyiv: NAU. (in Ukrainian).

3. Azarov, S. I., Sydorenko, V. L., \& Zadunay, O. S. (2017). Analiz kharakterystyk isnuyuchykh ecosystem. Naukovo-praktychnyy zhurnal «Ekolohichni nauky», (3-4), 77-85. (in Ukrainian).

4. Azarov, S., Sydorenko, V., \& Zadunaj, O. (2017). Determination of the reliability of ecosystems to the factor of anthropogenic pressure. Environmental Safety and Natural Resources, 24(3-4), 50-57. (in Ukrainian).

5. Azarov, S., \& Zadunaj, O. (2018). Modeling of ecosystem sustainability. Ekolohichni nauky, 23(4), 5-9. (in Ukrainian).

The article was received 06.07.2019 and was accepted after revision 30.07.2019

\section{Азаров Сергій Іванович}

доктор технічних наук, старший науковий співробітник, провідний науковий співробітник Інституту ядерних досліджень НАН України

Адреса робоча: 03680 Україна, м. Київ, пр-т Науки, 47

ORCID ID 0000-0002-9951-8867e-mail: azarov@kinr.kiev.ua

\section{Задунай Олексій Сергійович}

кандидат технічних наук, начальник центру Державного науково-дослідного інституту спеціального зв'язку та захисту інформації

Адреса робоча: 03142 Україна, м. Київ, вул. М. Залізняка, 6

ORCID ID 0000-0001-8589-1604 e-mail: a.zadunaj@gmail.com 